\title{
3D Pertumbuhan Kedelai Pada Pemberian Variasi Dosis Formula Pupuk Organik Cair dan Urea Menggunakan Anfis Berbasis XL System
}

\author{
Angga Debby Frayudha, Suhartono, Suyono
}

\begin{abstract}
Soybean Glycine max (L.) Merrill var. Willis is one of the food crops and has become a staple in Indonesia. With the development of current technology soybean plants begin to be simulated in 3D using the Groimp application based on the XL System, to prove the growth simulation conducted research, using organic fertilizer and urea fertilizer in different treatments. This study aims to determine the effect of fertilization with liquid organic fertilizer on plant productivity. Fertilization treatment treatments are: $P 1(3 \mathrm{ml}$ organic fertilizer / 1 liter of water / Afternoon), P2 (3 ml of organic fertilizer / 1 liter of water / Morning), P3 (2 g urea fertilizer / 1 liter of water / Afternoon), P4 ( 2 gr urea fertilizer / 1 liter of water / morning). The parameters observed were plant height, stem length, number of branches, number of leaves. The data obtained are entered and calculated using ANFIS after the training process, the smallest error is obtained and from there the selection of plants will be simulated in 3D. The results showed that fertilizing with urea fertilizer can increase soybean crop productivity compared to using Liquid Organic fertilizer. In the study found etiolation of plants, plants moved to a more spacious place on the 28th day apparently did not have a significant effect on plants that should have aged soybeans flowering at 35-40 days turned out not to flower, so it is expected that season crops should be planted on the season for maximum results and environmental conditions must be considered.
\end{abstract}

Index Terms - 3D, ANFIS, Glycine max (L.) Merrill var. Willis, Groimp, XL System.

Abstrak-- Kedelai Glycine max (L.) Merrill var. Willis merupakan salah satu tanaman pangan dan sudah menjadi kebutuhan pokok di indonesia. Dengan berkembangnya teknologi sekarang ini tanaman kedelai mulai disimulasikan dalam bentuk 3D menggunakan aplikasi

Manuscript received February 22, 2020. This work was supported in part by Informatics Engineering Department of Maulana Malik Ibrahim Islamic State University.

Angga D Frayudha is with the Informatic Engineering Departement of Maulana Malik Ibrahim Islamic State University, Malang, Indonesia (email: mpyenk@gmail.com )

Suhartono, with the Informatic Engineering Departement of Maulana Malik Ibrahim Islamic State University, Malang, Indonesia (email: galipek@gmail.com )

Suyono, with the Biology Departement of Maulana Malik Ibrahim Islamic State University, Malang, Indonesia (email: mr.yonshu@gmail.com )
Groimp yang berbasis XL System, untuk membuktikan simulasi pertumbuhan dilakukan penelitian, menggunakan pupuk organik dan pupuk urea pada perlakuan yang berbeda. Penelitian ini bertujuan untuk mengetahui pengaruh pemupukan dengan pupuk organik cair terhadap produktivitas tanaman. Perlakuan dosis pemupukan yaitu : P1 (3 ml pupuk organik/1 liter air/Sore), P2 (3 ml pupuk organik/1 liter air/Pagi), P3 (2 gr pupuk urea/1 liter air/Sore), $\mathbf{P 4}$ (2 gr pupuk urea/1 liter air/Pagi). Parameter yang diamati yaitu tinggi tanaman, panjang batang, jumlah cabang, jumlah daun. Data yang diperoleh dimasukan dan dihitung menggunakan ANFIS setelah proses training didapat error terkecil dan dari situlah pemilihan tanaman akan disimulasikan dalam bentuk 3D. Hasil penelitian menunjukkan bahwa pemupukan dengan pupuk urea dapat meningkatkan produktivitas tanaman kedelai dibandingkan dengan menggunakan pupuk Organik Cair. Pada penelitian didapat tumbuhan mengalami etiolasi, tanaman dipindah ke tempat yang lebih lapang pada hari ke 28 ternyata tidak memberi pengaruh signifikan terhadap tanaman yang semestinya umur kedelai sudah berbunga pada umur ke 35-40 hari ternyata belum berbunga, sehingga diharapkan tanaman musim memang harus ditanam pada musimnya agar hasilnya maksimal serta kondisi lingkungan harus diperhatikan.

Kata Kunci-3D, ANFIS, Glycine max (L.) Merrill var. Willis, Groimp, XL System.

\section{PENDAHULUAN}

$\mathbf{K}$ edelai atau biasa dipanggil kacang kedelai adalah salah satu tanaman polong-polongan yang menjadi bahan dasar banyak makanan dari Asia Timur seperti kecap, tahu, dan tempe. Tanaman kedelai berbatang pendek $(30-100 \mathrm{~cm})$, berbentuk tanaman perdu, dan berkayu. Batang tanaman kedelai biasanya kaku dan tahan rebah, kecuali yang dibudidayakan di musim hujan atau tanaman yang hidup di tempat yang ternaungi [1].

Pemupukan adalah hal mutlak yang akan digunakan guna mendapatkan hasil yang optimal dari suatu tanaman, dari situlah bermacam-macam penelitian dilakukan guna mendapatkan cara pemupukan yang terbaik bagi tanaman. Pada penelitian ini dilakukan suatu perlakuan pemupukan dengan pola yang terstuktur dengan pemupukan menggunakan pupuk organik dan urea serta 
mebedakan waktu pemupukan antara pemupukan sore hari dan pagi hari, berikut rancangan penelitian secara singkat perlakuan 1 menggunakan pupuk organik cair $3 \mathrm{ml} /$ liter dilakukan sore hari, perlakuan 2 menggunakan pupuk organik cair $3 \mathrm{ml} /$ liter dilakukan pagi hari, perlakuan 3 menggunakan pupuk urea 2gr/liter dilakukan sore hari, perlakuan 4 menggunakan pupuk urea 2gr/liter dilakukan pagi hari sehingga mendapatkan data morfologi tanaman yang akan menjadi inputan dalam program simulasi.

Pada pemodelan pertumbuhan tanaman yang menggambarkan unsur hayati tanaman yang bersifat dinamis dan kompleks akan sangat sulit didekati dengan persamaan matematis dan geometric konvensional. para ilmuwan sekarang telah mematahkan dengan kesimpulan bahwa proses alami sistem hidup pertumbuhan tanaman secara biologis dan bersifat kompleks yang dipengaruhi oleh karakteristik lingkungan, telah mampu dianalisis dan di sintesis dalam bentuk pemodelan kehidupan buatan yang meyerupai lingkungan alamiahnya dengan pendekatan XL-System. Tujuan penelitian ini untuk memodelkan bentuk, ukuran dan jumlah struktur tanaman dengan menggunakan metode ANFIS, dan mendapatkan pola dari aturan-aturan yang membentuk jenis tanaman seperti aslinya.

Untuk menghasilkan suatu bentuk dengan metode ini harus dilakukan dua langkah, yaitu aplikasi dari grammar untuk menghasilkan string berisi struktur topologi dari pohon dan interprestasi dari string tersebut. Untuk langkah pertama, dilakukan dengan metode rekursif, dan untuk langkah kedua, dilakukan dengan metode iteratif. Implementasi dari aplikasi ini menggunakan software GroImp untuk menvisualisasikan bentuk tanaman.

Pendekatan analisis numerik terhadap sistem fuzzy pertama kali digagas oleh Tagaki dan Sugeno [2] dan setelah itu banyak sekali studi yang terkait dengan hal tersebut. Sistem yang berbasis fuzzy biasa dinyatakan dengan pengetahuan berbentuk "IF-THEN" yang memberikan keuntungan tidak memerlukan analisis matematik untuk pemodelan. Sistem seperti ini bisa memproses penalaran dan pengetahuan manusia yang berorientasi pada aspek kualitatif. Seperti diketahui, pemodelan matematik semacam persamaan diferensial tidak tepat untuk menangani sistem yang menghadapi keadaan tidak menentu atau terdefinisi tidak bagus [3]. Di sisi lain, neural network mempunyai keuntungan yang memudahkan dalam mengklasifikasikan suatu objek berdasarkan sekumpulan fitur yang menjadi masukan sistem. Dengan hanya memasukkan sejumlah fitur dan kemudian melakukan pelatihan menggunakan data tersebut, sistem berbasis neural network mampu membedakan antara satu objek dengan objek lain [4]. Sistem ini juga mempunyai kelebihan terhadap sistem konvensional diantaranya :

1.Anfis Mampu dan bisa melakukan akuisisi pengetahuan di bawah derau dan ketidakpastian.

2. Representasi pengetahuan bersifat fleksibel.

3. Toleran terhadap kesalahan.

Dengan mempertimbangkan kelebihan ANFIS, maka dalam paper ini mengimplementasikan metode ANFIS untuk menghitung error pada inputan tanaman dan diambil satu data dengan tanaman mana yang memiliki error terkecil dan dijadikan suatu model simulasi. Sistem inferensi fuzzy yang digunakan adalah sistem inferensi fuzzy model Tagaki-Sugeno-Kang (TSK) orde satu dengan pertimbangan kesederhanaan dan kemudahan komputasi. Sistem fuzzy inidigabungkan dengan algoritma pembelajaran neural network

\section{TINJAUAN PUSTAKA}

\section{A. Tanaman Kedelai}

Tanaman kedelai berbatang pendek $(30-100 \mathrm{~cm})$, memiliki 3-6 percabangan, berbentuk tanaman perdu, dan berkayu. Batang tanaman kedelai biasanya kaku dan tahan rebah, kecuali yang dibudidayakan di musim hujan atau tanaman yang hidup di tempat yang ternaungi [1], menambahkan bahwa pertumbuhan batang kedelai dibedakan menjadi dua tipe yaitu tipe determinate dan indeterminate, keduanya dibedakan berdasarkan atas keberadaan bunga pada pucuk batang. Pertumbuhan batang tipe determinate ditunjukkan dengan batang yang tidak tumbuh lagi pada saat tanaman mulai berbunga. Sedangkan pertumbuhan indeterminate dicirikan dengan pucuk batang tetap tumbuh daun, walaupun tanaman sudah mulai berbunga.

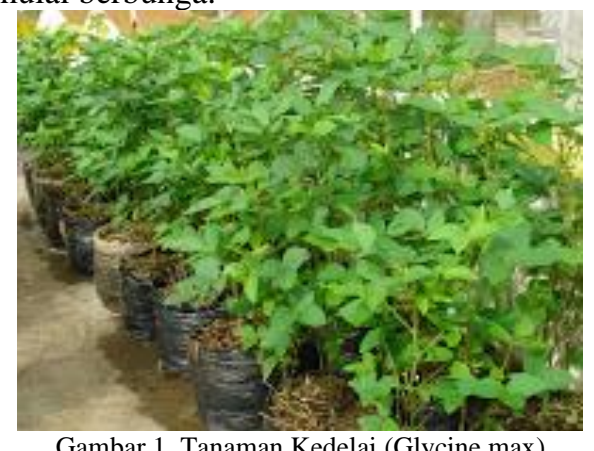

\section{B. Tercekam Naungan}

Menurut Handayani [5], cekaman naungan 50\% menyebabkan hasil tanaman kedelai menurun $10-40 \%$. karena kedelai memerlukan intensitas cahaya yang cukup tinggi untuk berfotosintesis. Tanaman kedelai yang tumbuh dalam kondisi intensitas cahaya rendah akan mengalami etiolasi, yaitu pertumbuhan memanjang tetapi lemah dan mudah rebah.

\section{Pupuk Urea}

urea merupakan salah satu bentuk $\mathrm{N}$ sintetis yang mempunyai sifat larut dalam air dan cepat menguap. Secara ekonomis pemakaian urea sebagai sumber $\mathrm{N}$ lebih menguntungkan karena kadar $\mathrm{N}$ nya cukup tinggi $(46 \%)$ [6].

\section{Pupuk Organik Cair}

Pupuk organik cair adalah larutan dari pembusukan bahan-bahan organik yang berasal dari sisa tanaman, kotoran hewan, dan manusia yang kandungan unsure haranya lebih dari satu unsure. Kelebihan dari pupuk organik ini adalah dapat secara cepat mengatasi defesiensi hara, pupuk ini juga memiliki bahan pengikat, sehingga larutan pupuk yamg diberikan ke permukaan tanah bisa langsung digunakan oleh tanaman. Dengan menggunakan pupuk organik cair dapat mengatasi masalah lingkungan dan membantu menjawab 
kelangkaan dan mahalnya harga pupuk anorganik saat ini [7].

\section{E. XL-System}

XL-System (eXtended Lindenmayer System) merupakan penggabungan konsep L-system dengan bahasa pemrograman XL. Bahasa pemrograman XL ini sendiri merupakan bahasa pemrograman java yang mengumplementasikan Relational Growth Grammars (RGG). XL dibangun dengan bahasa java dan menerapkan algoritma L-System

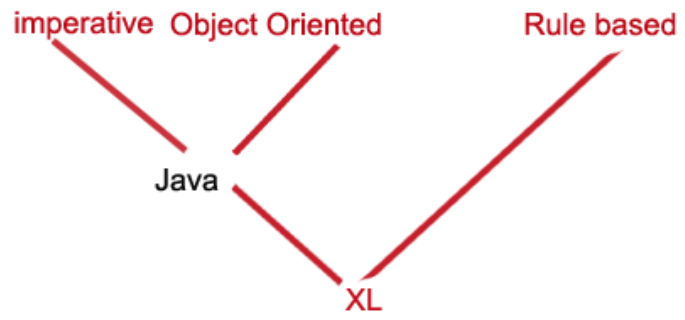

Gambar 2. Skema Sederhana XL-System

\section{F. Adaptive Neuro Fuzzy Inference System (ANFIS)}

ANFIS (Adaptive Neuro Fuzzy Inference System atau Adaptive Networkbased Fuzzy Inference System) adalah arsitektur yang secara fungsional sama dengan fuzzy rule base model Sugeno. Arsitektur ANFIS juga sama dengan jaringan syaraf dengan fungsi radial dengan sedikit batasan tertentu. Bisa dikatakan bahwa ANFIS adalah suatu metode yang mana dalam melakukan penyetelan aturan digunakan algoritma pembelajaran terhadap sekumpulan data [8]

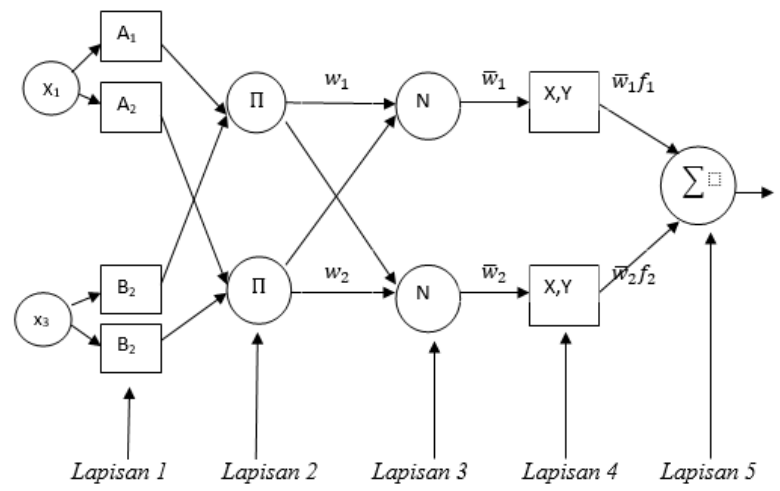

Gambar 3. Struktur ANFIS (Sri Kusumadewi, 2010)

pemodelan matematik semacam persamaan diferensial tidak tepat untuk menangani sistem yang menghadapi keadaan tidak menentu atau terdefinisi tidak bagus [3]

\section{G. GroIMP}

GroIMP (Growth Grammar-related Interactive Modelling Platform). Seperti namanya, groIMP merupakan software yang digunakan sebagai modeling3D yang memiliki beberapa fitur diantaranya :

- Interaktif dalam mengedit adegan.

- Kaya set objek 3D, mudah dimengerti bagi orang awam.

- Banyak pilihan seperti warna dan tekstur.

- Seperti waktu sebenarnya menggunakan OpenGL.

- Bisa di eksport ke POV-Ray, dengan tambahan ray-tracer.
- Bisa di eksport ke DXF, sebagian bisa di eksport ke VRML/3XD.

Built-in raytracer Twilight merender adegan.

\section{H. Penelitian Terkait}

Simulasi 3D Pertumbuhan sudah mulai digunakan di era industri 4sekarang ini untuk mempermudah ujicoba tanaman dengan perlakuan yang berbeda sehingga mengurangi kerugian jika menanam langsung tanaman tanpa adanya uji coba terlebih dahulu.

Untuk mendukung penelitian ini maka didukung penelitian lain misalnya pada penelitian [12] Menjelaskan parametrik stochastic L-systems yang dimanfaatkan untuk memprediksi visualisasi gambar tiga dimensi batang tanaman dengan mengikutsertakan ketebalan batang serta beberapa kemungkinan pada model tanaman yang terbentuk dari foto objek asli. Penelitian lainnya [13] memaparkan Simulasi Tanaman Tecnomatix (oleh Siemens) untuk mensimulasikan proses produksi dan logistik. Alat ini memungkinkan untuk mensimulasikan kejadian diskrit dan membuat model digital dari sistem logistik (misalnya produksi), mengoptimalkan operasi pabrik produksi, jalur produksi, serta proses logistik individu. dengan penggunaan algoritma genetika dan jaringan saraf tiruan.

Sementara itu dalam penelitian [14] Pemodelan didefinisikan sebagai penyederhanaan sistem dengan pendekatan mekanistik, dapat menjadi pendekatan alternatif untuk pemahaman dan prediksi proses ekofisiologi pertumbuhan, pengembangan dan produksi pabrik. Pemodelan pertumbuhan tanaman tebu diharapkan dapat digunakan sebagai alat untuk memprediksi produksi produksi tebu serta di daerah pengembangan. Pada penelitian lain [15] Menjelaskan bahwa hasil simulasi dapat diterapkan untuk memprediksi produksi tanaman padi. Metode yang digunakan dalam penelitian ini adalah model neraca air, model pertumbuhan dan pengembangan melalui Simulasi Pemodelan Dinamis. Hasil penelitian menunjukkan bahwa waktu tanam yang optimal dapat diprediksi dari model simulasi.

Selain itu pada penelitian [16] Penelitian lain menyimpulkan bahwa untuk mendapatkan model pertumbuhan dan produksi kelapa sawit untuk berbagai tingkat pemangkasan daun. Percobaan dilakukan di PT. Astra Agro Lestari, Pangkalan Bun, Kalimantan Tengah, dari Agustus 2010 hingga Februari 2012. Percobaan disusun dalam rancangan acak kelompok dengan dua faktor dan tiga ulangan untuk setiap usia kelapa sawit.

\section{METODE PENELITIAN}

Dalam pembuatan Aplikasi Simulasi Pertumbuhan kedelai ini menggunakan metode penelitian dan pengembangan atau Research and Development (R\&D) adalah metode penelitian yang digunakan untuk menghasilkan produk tertentu dan menguji keefektifan produk tersebut. Menurut Sugiyono langkah-langkah penggunaan metode penelitian dan pengembangan atau Research and Development (R\&D) [9] adalah sebagai berikut: 


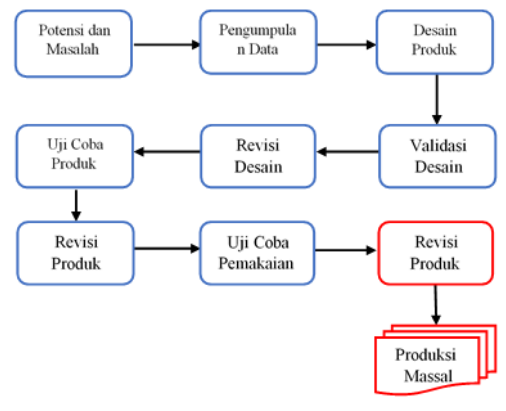

Gambar 4. Alur R \& D

Dalam penelitian ini digunakan beberapa langkah penggunaan metode penelitian dan pengembangan atau Research and Development (R\&D) sebagai sarana untuk memahami objek masalah. Adapun dalam pembuatan metode penelitian, peneliti menggunakan 8 tahapan atau langkah metode penelitian dan pengembangan atau Research and Development (R\&D) menurut Sugiyono yang meliputi potensi dan masalah, pengumpulan data, desain produk, validasi desain, revisi desain, uji coba produk, revisi produk, uji coba pemakaian [9].

Terlebih dahulu dan Pada Penelitian ini ada beberapa tahapan yang dilakukan untuk mempermudah pembuatan program simulasi pertumbuhan kedelai pada pemberian variasi pupuk urea dan beberapa macam pupuk organik/ pupuk hayati mengunakan metode ANFIS( Adaptive Neuro Fuzzy Inference System) berbasis XL system.

\section{a) Observasi}

Pada tahapan ini peneliti melakukan penelitian/observasi tanaman kedelai varietas wilis ke tempat persawahan joyogrand malang, observasi ditempat penelitian meliputi mencatat data terkait penelitian ini, pengamatan langsung mengenai morfologi tumbuhan kedelai berlangsung di persawahan joyogrand malang dengan menanam bibit kedelai di polybag.

\section{b) Penelitian}

Penelitian yang dilakukan disini adalah melihat pengaruh perlakuan waktu penyiraman dan dosis pupuk urea atau pupuk organik cair terhadap pertumbuhan serta perkembangan tanaman kedelai varietas wilis, yaitu dengan cara mengukur morfologi tanaman. Selanjutnya data morfologi tanaman ini digunakan sebagai variabel inputan ANFIS dimana outputnya digunakan untuk mensimulasikan salah satu dari jumlah keseluruhan satu kelompok.

Tabel 1. Kegiatan Penelitian

\begin{tabular}{|c|l|c|}
\hline No & \multicolumn{1}{|c|}{ Kegiatan } & Waktu Pelaksanaan \\
\hline 1 & Mempersiapkan bahan penelitian & 2 Januari 2013 \\
\hline 2 & $\begin{array}{l}\text { Mengisi Polybag dengan tanah } \\
\text { sawah }\end{array}$ & 3 Januari 2013 \\
\hline 3 & Penanaman kedelai & 6 Januari 2013 \\
\hline 4 & $\begin{array}{l}\text { Pemupukan pertama dan penyangan } \\
\text { rumput }\end{array}$ & 13 Januari 2013 \\
\hline 5 & Pengambilan data & 13 Januari 2013 \\
\hline 6 & $\begin{array}{l}\text { Pemupukan kedua dan penyangan } \\
\text { rumput }\end{array}$ & 20 Januari 2013 \\
\hline 7 & Pengambilan data & 20 Januari 2013 \\
\hline 8 & $\begin{array}{l}\text { Pemupukan ketiga dan penyiangan } \\
\text { rumput }\end{array}$ & 27 Januari 2013 \\
\hline 9 & Pengambilan data & 27 Januari 2013 \\
\hline 10 & $\begin{array}{l}\text { Pemupukan keempat dan } \\
\text { penyiangan rumput }\end{array}$ & 3 Februari 2013 \\
\hline 11 & Pengambilan data & 3 Februari 2013 \\
\hline 12 & Pemupukan kelima dan penyiangan & 10 Februari 2013 \\
\hline
\end{tabular}

\begin{tabular}{|c|l|c|}
\hline & rumput & \\
\hline 13 & Pengambilan data & 10 Februari 2013 \\
\hline 14 & $\begin{array}{l}\text { Pemupukan kelima dan penyiangan } \\
\text { rumput }\end{array}$ & 17 Februari 2013 \\
\hline 15 & Pengambilan data & 17 Februari 2013 \\
\hline 16 & $\begin{array}{l}\text { Pengambilan keenam dan } \\
\text { penyiangan rumput }\end{array}$ & 18 Februari 2013 \\
\hline 17 & Pengambilan data & 3 Maret 2013 \\
\hline 18 & Pengambilan data & 15 Maret 2013 \\
\hline
\end{tabular}

\section{c) Analisa Data}

Penarikan kesimpulan mengenai observasi yang telah dilakukan dan data yang diperoleh setelah penelitian, meliputi data morfologi tanaman dan pemberian dosis urea dan pupuk organik, dan pada tahap ini bisa ditarik kesimpulan dari pengaruh pupuk urea dan pupuk organik terhadap pertumbuhan tanaman kedelai varietas wilis. Dan dari kesimpulan ini kita bisa membuat model pertumbuhan tanaman kedelai varietas wilis per parameter.

\section{d) Perancangan Program}

pada tahapan ini dilakukan pembuatan rancangan program yang akan dibangun tadi agar sesuai dengan objek yang diteliti dari analisa data.

\section{e) Pembuatan Program}

Pada tahapan ini pembuatan program akan mulai dikerjakan sesuai dengan data yang didapat dari membuat rancangan program dengan membangun program simulasi dan mengolah data-data yang ada sesuai dengan inputan.

Teknologi yang digunakan dalam pembuatan dan pengembangan sistem ini adalah menggunakan teknologi simulasi berbasis XL System (extended lindenmayer sistem). Dengan teknologi ini, memungkinkan kompleksitas alam dapat didefinisikan dengan beberapa parameter dan aturan. Perulangan iterasi merupakan struktur kontrol perulangan yang umumnya menggunakan perintah-perintah yang telah tersedia pada bahasa pemrograman, setiap bahasa pemrograman mempunyai perintah perulangan yang berbeda-beda. Dalam perulangan iterasi, proses perulangan akan dilakukan jika kondisi untuk memulai proses perulangan terpenuhi dan akan berhenti jika kondisi untuk menghentikan perulangan terpenuhi [10].

\section{f) Evaluasi Program}

Evaluasi ini bertujuan untuk memastikan program telah benar sesuai dengan rancangan dan juga untuk memastikan bahwa metode dan rumus-rumus pada program sudah benar sehingga diharapkan tidak ada kesalahan pada program tersebut.

\section{PEMBAHASAN}

Hasil dari perlakuan jenis pupuk dan waktu pemupukan diperoleh data berupa morfologi tanaman kedelai Glycine $\max ($ L.) Merill varietas wilis dan dan yang menjadi indikator adalah tinggi tanaman, panjang batang, banyak cabang dan banyak daun. Namun tanaman kedelai tidak tumbuh dengan optimal dikarenakan faktor lingkungan, cuaca yang memang ditanam bukan pada musimnya. Selanjutnya data morfologi tanaman ini digunakan sebagai variabel 
inputan ANFIS dimana outputnya digunakan untuk mensimulasikan salah satu dari jumlah keseluruhan dari satu perlakuan.

\subsection{Analisa data}

Kondisi lingkungan dan iklim pada bulan januari sampai maret yang memang musim hujan menyebabkan pertumbuhan kedelai mengalami masalah yaitu tanaman mengalami etiolasi dan di dukung dengan lingkungan yang memang tidak mendukung pertumbuhan karena tidak pada tempat yang lapang. mulai pada umur 1-26 hari dan setelah pemindahan pada hari ke 28 ke tempat yang lebih lapang pun tanaman masih menunjukan gejala etiolasi. Cahaya matahari juga berpengaruh, intensitas cahaya matahari rata-rata pada bulan Januari sebesar $230.61 \mathrm{cal} / \mathrm{cm}^{2} /$ hari dan terendah $217.82 \mathrm{cal} / \mathrm{cm}^{2} /$ hari.

Keadaan iklim tersebut menunjukan kondisi cuaca tidak optimum untuk pertumbuhan tanaman kedelai. Secara umum kondisi tanaman pada umur 35 keatas yang pada dasarnya pertumbuhan vegetatif kedelai mengalami proses pembungaan namun tidak mengalami hal tersebut

Kombinasi Pupuk Organik dan Pemupukan waktu sore tidak begitu berpengaruh terhadap pertumbuhan tanaman, hasil yang paling nampak adalah pemupukan urea atau pupuk Anorganik dengan pemupukan waktu sore berpengaruh terhadap diameter batang, tinggi tanaman, banyak cabang dan banyak daun.

\subsubsection{Variabel Penelitian}

a. Variabel bebas dalam penelitian ini adalah dosis pupuk urea yang berbeda dengan dosis pupuk organik yang berbeda.

b. Variabel terikat dalam penelitian ini adalah pertumbuhan dan perkembangan tanaman pangan kedelai yang meliputi tinggi tanaman, panjang tanaman, banyak cabang, dan banyak daun.

Tabel 2. data tanaman kedelai umur 60 hari

\begin{tabular}{|c|c|c|c|c|}
\hline No & $\begin{array}{c}\text { Tinggi } \\
\text { tanaman }(\mathrm{cm})\end{array}$ & $\begin{array}{c}\text { Panjang } \\
\text { batang }(\mathrm{cm})\end{array}$ & $\begin{array}{c}\text { Banyak } \\
\text { Cabang }\end{array}$ & $\begin{array}{c}\text { Banyak } \\
\text { Daun }\end{array}$ \\
\hline 1 & 33.2 & 30.3 & 10 & 36 \\
\hline 2 & 28.7 & 25.2 & 10 & 33 \\
\hline 3 & 28.3 & 22.4 & 10 & 33 \\
\hline 4 & 33.7 & 30.1 & 11 & 33 \\
\hline 5 & 33.2 & 30.5 & 11 & 30 \\
\hline 6 & 31.5 & 28.7 & 10 & 33 \\
\hline 7 & 34.2 & 30.5 & 10 & 30 \\
\hline 8 & 28.3 & 24.9 & 10 & 33 \\
\hline 9 & 25.8 & 20.3 & 10 & 33 \\
\hline 10 & 25.2 & 20.6 & 10 & 33 \\
\hline 11 & 30.2 & 25.2 & 11 & 30 \\
\hline 12 & 24.4 & 20.9 & 10 & 36 \\
\hline 13 & 27.1 & 20.1 & 10 & 36 \\
\hline 14 & 26.2 & 20.7 & 10 & 36 \\
\hline 15 & 25.2 & 20.2 & 10 & 36 \\
\hline 16 & 32.6 & 25.6 & 11 & 30 \\
\hline 17 & 22.6 & 19.2 & 10 & 36 \\
\hline 18 & 25.4 & 20.8 & 10 & 36 \\
\hline 19 & 29.4 & 25.2 & 10 & 33 \\
\hline 20 & 30.8 & 25.9 & 10 & 33 \\
\hline & & & & \\
\hline
\end{tabular}

Setelah didapat hasil dari pengamatan data morfologi tanaman selanjutnya dilakukan proses pengolahan data oleh ANFIS

\subsection{Pengolahan Data}

Dalam kasus ini terdiri dari dua input $\mathrm{X}_{1}$ dan $\mathrm{X}_{2}$ dan satu output $\mathrm{Y}$, dimana $\mathrm{X}_{1}$ adalah panjang batang, $\mathrm{X}_{2}$ adalah banyak daun dan Y adalah tinggi tanaman. Maka didapat aturan model sugeno :

If $X_{1}$ is $A_{1}$ dan $X_{2}$ is $B_{1}$ dan Then $Y_{1}$

$$
=C_{11} X_{1}+C_{12} X_{2}+C_{10}
$$

$$
\begin{aligned}
& \text { If } X_{1} \text { is } A_{2} \text { dan } X_{2} \text { is } B_{2} \text { dan Then } Y_{2} \\
& =C_{21} X_{1}+C_{22} X_{2}+C_{20}
\end{aligned}
$$

Maka didapat rata-rata terbobot

$$
Y=\frac{W_{1} Y_{1}+W_{2} Y_{2}}{W_{1}+W_{2}}=\overline{W_{1}} Y_{1}+\overline{W_{2}} Y_{3}
$$

Setelah itu data diolah dan terlebih dahulu dicari nilai $\mathrm{a}_{\mathrm{i}}, \mathrm{b}_{\mathrm{i}}$ dan $\mathrm{c}_{\mathrm{i}}$ menggunakan persamaan dibawah ini

$S=\sqrt{\frac{\sum_{i=1}^{n}\left(X_{i}-\bar{X}\right)^{2}}{n-1}}$

Dan didaptkan hasil

$\bar{X}=\frac{1}{n} \sum_{i=1}^{n} X$

Setelah didapat hasil menggunakan persamaan diatas didapat nilai $a_{i}, b_{i}$ dan $c_{i}$ setelah itu baru dihitung menggunakan jaringan ANFIS (Adaptive Neuro Fuzzy Inference System) gambar jaringan ANFIS dapat dilihat dibawah ini

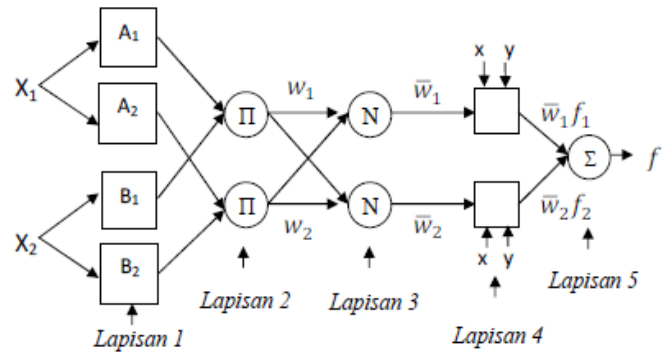

Gambar 5. Arsitektur ANFIS

(1) Lapisan 1

Berfungsi untuk membangkitkan derajat keanggotaan dengan persamaan dibawah ini

Tabel 3. Hasil Layer 1

\begin{tabular}{|c|c|c|c|ccc|}
\hline \multirow{2}{*}{$\begin{array}{c}\text { Data } \\
\text { ke }\end{array}$} & \multicolumn{3}{|c|}{ Input } & \multicolumn{3}{c|}{ Hasil } \\
\cline { 2 - 7 } & $\mathrm{X}_{\mathrm{i}}$ & $\mathrm{X}_{2}$ & $\mathrm{X}_{3}$ & $\mu A_{1}\left(X_{1}\right)$ & $\mu B_{1}\left(X_{2}\right)$ & $\mu D_{1}\left(X_{3}\right)$ \\
\hline 1 & 0.40 & $\begin{array}{c}10.1 \\
2\end{array}$ & 0.36 & 0.439 & 0.077 & 0.816 \\
\hline 2 & 0.36 & 0.11 & 0.33 & 0.816 & 0.071 & 1.0 \\
\hline
\end{tabular}




\begin{tabular}{|c|c|c|c|c|c|c|}
\hline 3 & 0.30 & 0.11 & 0.33 & 0.795 & 0.071 & 1.0 \\
\hline 4 & 0.35 & 0.11 & 0.33 & 0.912 & 0.071 & 1.0 \\
\hline 5 & 0.20 & 0.10 & 0.30 & 0.178 & 0.065 & 0.795 \\
\hline 6 & 0.30 & 0.11 & 0.33 & 0.795 & 0.071 & 1.0 \\
\hline 7 & 0.30 & 0.10 & 0.30 & 0.795 & 0.065 & 0.795 \\
\hline 8 & 0.30 & 0.11 & 0.33 & 0.795 & 0.071 & 1.0 \\
\hline 9 & 0.30 & 0.11 & 0.33 & 0.795 & 0.071 & 1.0 \\
\hline 10 & 0.30 & 0.11 & 0.33 & 0.795 & 0.071 & 1.0 \\
\hline 11 & 0.32 & 0.10 & 0.30 & 0.969 & 0.065 & 0.795 \\
\hline 12 & 0.38 & 0.12 & 0.36 & 0.608 & 0.077 & 0.816 \\
\hline 13 & 0.40 & 0.12 & 0.36 & 0.439 & 0.077 & 0.816 \\
\hline 14 & 0.40 & 0.12 & 0.36 & 0.439 & 0.077 & 0.816 \\
\hline 15 & 0.40 & 0.12 & 0.36 & 0.439 & 0.077 & 0.816 \\
\hline 16 & 0.20 & 0.10 & 0.30 & 0.178 & 0.065 & 0.795 \\
\hline 17 & 0.38 & 0.12 & 0.36 & 0.608 & 0.077 & 0.816 \\
\hline 18 & 0.40 & 0.12 & 0.36 & 0.439 & 0.077 & 0.816 \\
\hline 19 & 0.30 & 0.11 & 0.33 & 0.795 & 0.071 & 1.0 \\
\hline 20 & 0.32 & 0.11 & 0.33 & 0.969 & 0.071 & 1.0 \\
\hline
\end{tabular}

(2) Lapisan 2

Tiap-tiap neuron pada lapisan kedua berupa neuron tetap yang outputnya adalah hasil dari lapisan pertama. Biasanya digunakan operator AND. Lapisan ini berfungsi untuk membangkitkan firing-strength dengan mengalikan setiap sinyal masukan [11].

Tabel 4. Hasil Layer 2

\begin{tabular}{|c|c|c|c|c|c|c|}
\hline \multirow{2}{*}{$\begin{array}{c}\text { Data } \\
\text { ke }\end{array}$} & \multicolumn{3}{|c|}{ Input } & \multicolumn{3}{|c|}{ Hasil } \\
\hline & $\mu A_{1}\left(X_{1}\right)$ & $\mu B_{1}\left(X_{2}\right)$ & $\mu D_{1}\left(X_{3}\right)$ & $\mathrm{W}_{1}$ & $\mathrm{~W}_{2}$ & $\mathrm{~W}_{2}$ \\
\hline 1 & 0.439 & 0.077 & 0.816 & 0.028 & 0.04 & 0.007 \\
\hline 2 & 816 & 0.071 & 1.0 & 0.058 & $0.05^{\prime}$ & 0.01 \\
\hline 3 & 0.795 & 0.071 & 1.0 & 0.056 & 0.095 & 0.01 \\
\hline 4 & 0.912 & 0.071 & 1.0 & 0.065 & 0.062 & 0.01 \\
\hline 5 & 0.178 & 0.065 & 0.795 & 0.0090 & 0.322 & 0.08 \\
\hline 6 & .795 & 0.071 & 1.0 & 0.056 & 0.09 & 0.01 \\
\hline 7 & 795 & 0.065 & 0.795 & 0.041 & 0.09 & 0.02 \\
\hline 8 & 795 & 0.071 & 1.0 & 0.056 & 0.095 & 0.01 \\
\hline 9 & 0.795 & 0.071 & 1.0 & 0.056 & 0.09 & 0.01 \\
\hline 10 & 0.795 & 0.071 & 1.0 & 0.056 & 0.095 & 0.01 \\
\hline 11 & 969 & 0.065 & 0.795 & 0.05 & 0.078 & 0.02 \\
\hline 12 & 608 & 0.0 & 0.816 & 0.038 & 0.04 & 0.008 \\
\hline 13 & & & 816 & 0.0 & 0.04 & 0.007 \\
\hline 14 & 439 & 0.077 & 816 & 0.02 & 0.04 & 0.00 \\
\hline 15 & 439 & 0.077 & 0.816 & 0.028 & 0.04 & $0.00^{-1}$ \\
\hline 16 & 178 & 0.065 & 0.795 & 0.0090 & 0.322 & 0.08 \\
\hline 17 & 608 & 0.0 & 0.816 & 0.038 & 0.04 & 0.008 \\
\hline 18 & & 0.0 & 0.816 & 0.02 & 0.04 & 0.007 \\
\hline 19 & & & 1.0 & 0.056 & 0.09 & 0.01 \\
\hline 20 & 0.969 & 071 & 1.0 & 0.069 & 0.079 & 0.0 \\
\hline \multicolumn{7}{|c|}{$\begin{array}{l}\text { Fungsi dari lapisan ini untuk menormalkan firing } \\
\text { strength [11]. } \\
\text { Tabel 5. Hasil Layer } 3\end{array}$} \\
\hline \multirow{2}{*}{$\begin{array}{l}\text { Data } \\
\text { ke- }\end{array}$} & \multicolumn{3}{|c|}{ Input } & \multicolumn{3}{|c|}{ Hasil } \\
\hline & $w_{i}$ & $w_{2}$ & $w_{3}$ & $\bar{w}_{i}$ & $\bar{w}_{2}$ & $\bar{w}_{2}$ \\
\hline 1 & 0.028 & 0.043 & 0.0070 & 0.246 & 0.377 & 0.377 \\
\hline 2 & 0.058 & 0.057 & 0.011 & 0.337 & 0.331 & 0.331 \\
\hline 3 & 0.056 & 0.095 & .019 & 0.228 & 0.386 & 0.386 \\
\hline 4 & 0.065 & 0.062 & 0.012 & 0.344 & 0.328 & 0.328 \\
\hline 5 & 0.0090 & 0.322 & 0.081 & 0.014 & 0.493 & 0.493 \\
\hline 6 & 0.056 & 0.095 & 0.019 & 0.228 & 0.386 & 0.386 \\
\hline 7 & 0.041 & 0.094 & 0.024 & 0.179 & 0.41 & 0.41 \\
\hline 8 & 0.056 & 0.095 & 0.019 & 0.228 & 0.386 & 0.386 \\
\hline 9 & 0.056 & 0.0 & & 0.228 & 0.386 & 0.386 \\
\hline 10 & 0.056 & 0.095 & 0.019 & 0.228 & 0.386 & 0.386 \\
\hline 11 & 0.05 & 0.078 & 0.02 & 0.243 & 0.379 & 0.379 \\
\hline 12 & 0.038 & 0.049 & 0.0080 & 0.279 & 0.36 & 0.36 \\
\hline 13 & 0.028 & 0.043 & 0.0070 & 0.246 & 0.377 & 0.377 \\
\hline 14 & 0.028 & 0.043 & 0.0070 & 0.246 & 0.377 & 0.377 \\
\hline 15 & 0.028 & 0.043 & 0.0070 & 0.246 & 0.377 & 0.377 \\
\hline 16 & 0.0090 & 0.322 & 0.081 & 0.014 & 0.493 & 0.493 \\
\hline
\end{tabular}

\begin{tabular}{|c|c|c|c|c|c|c|}
\hline 17 & 0.038 & 0.049 & 0.0080 & 0.279 & 0.36 & 0.36 \\
\hline 18 & 0.028 & 0.043 & 0.0070 & 0.246 & 0.377 & 0.377 \\
\hline 19 & 0.056 & 0.095 & 0.019 & 0.228 & 0.386 & 0.386 \\
\hline 20 & 0.069 & 0.079 & 0.016 & 0.304 & 0.348 & 0.348 \\
\hline
\end{tabular}

\section{(4) Lapisan 4}

Fungsi dari lapisan ini untuk Dalam penelitian ini untuk mendapatkan nilai awal $\left\{\mathrm{p}_{\mathrm{i}}, \mathrm{q}_{\mathrm{i}}\right.$ dan $\left.\mathrm{r}_{\mathrm{i}}\right\}$ Parameterparameter pada lapisan tersebut disebut dengan nama consequent parameter [11].

Tabel 6. Hasil Layer 4

\begin{tabular}{|c|c|c|c|c|c|c|}
\hline \multirow{2}{*}{$\begin{array}{c}\text { Data } \\
\text { ke }\end{array}$} & \multicolumn{3}{|c|}{ Input } & \multicolumn{3}{|c|}{ Hasil } \\
\hline 1 & 0.246 & 0.377 & 0.377 & 0.114 & 0.385 & 0.385 \\
\hline 2 & 0.337 & 0.331 & 0.331 & 0.143 & 0.285 & 0.285 \\
\hline 3 & 0.228 & 0.386 & 0.386 & 0.065 & 0.225 & 0.225 \\
\hline 4 & 0.344 & 0.328 & 0.328 & 0.138 & 0.267 & 0.267 \\
\hline 5 & 0.014 & 0.493 & 0.493 & 0.001 & 0.072 & 0.072 \\
\hline 6 & 0.228 & 0.386 & 0.386 & 0.065 & 0.225 & 0.225 \\
\hline 7 & 0.179 & 0.41 & 0.41 & 0.06 & 0.249 & 0.249 \\
\hline 8 & 0.228 & 0.386 & 0.386 & 0.065 & 0.225 & 0.225 \\
\hline 9 & 0.228 & 0.386 & 0.386 & 0.065 & 0.225 & 0.225 \\
\hline 10 & 0.228 & 0.386 & 0.386 & 0.065 & 0.225 & 0.225 \\
\hline 11 & 0.243 & 0.379 & 0.379 & 0.093 & 0.265 & 0.265 \\
\hline 12 & 0.279 & 0.36 & 0.36 & 0.117 & 0.334 & 0.334 \\
\hline 13 & 0.246 & 0.377 & 0.377 & 0.114 & 0.385 & 0.385 \\
\hline 14 & 0.246 & 0.377 & 0.377 & 0.114 & 0.385 & 0.385 \\
\hline 15 & 0.246 & 0.377 & 0.377 & 0.114 & 0.385 & 0.385 \\
\hline 16 & 0.014 & 0.493 & 0.493 & 0.001 & 0.072 & 0.072 \\
\hline 17 & 0.279 & 0.36 & 0.36 & 0.117 & 0.334 & 0.334 \\
\hline 18 & 0.246 & 0.377 & 0.377 & 0.114 & 0.385 & 0.385 \\
\hline 19 & 0.228 & 0.386 & 0.386 & 0.065 & 0.225 & 0.225 \\
\hline 20 & 0.304 & 0.348 & 0.348 & 0.1 & 0.235 & 0.235 \\
\hline
\end{tabular}
024 (5) Lapisan 5

.019 Menghitung sinyal keluaran ANFIS dengan 0.019 menjumlahkan semua sinyal yang masuk

\begin{tabular}{|c|c|c|c|c|c|c|}
\hline \multirow{2}{*}{$\begin{array}{c}\text { Data } \\
\text { ke }\end{array}$} & \multicolumn{7}{|c|}{ Input } & Hasil \\
\cline { 2 - 7 } & $\bar{w}_{1} f_{1}$ & $\bar{w}_{2} f_{2}$ & $\bar{w}_{3} f_{3}$ & $w_{1}$ & $w_{2}$ & $\sum \bar{w}_{i} f_{i}$ \\
\hline 1 & 0.114 & 0.385 & 0.385 & 0.028 & 0.043 & 11.333 \\
\hline 2 & 0.143 & 0.285 & 0.285 & 0.058 & 0.057 & 5.659 \\
\hline 3 & 0.065 & 0.225 & 0.225 & 0.056 & 0.095 & 3.029 \\
\hline 4 & 0.138 & 0.267 & 0.267 & 0.065 & 0.062 & 4.835 \\
\hline 5 & 0.0010 & 0.072 & 0.072 & 0.0090 & 0.322 & 0.352 \\
\hline 6 & 0.065 & 0.225 & 0.225 & 0.056 & 0.095 & 3.029 \\
\hline 8 & 0.06 & 0.249 & 0.249 & 0.041 & 0.094 & 3.509 \\
\hline 9 & 0.065 & 0.225 & 0.225 & 0.056 & 0.095 & 3.029 \\
\hline 10 & 0.065 & 0.225 & 0.225 & 0.056 & 0.095 & 3.029 \\
\hline 11 & 0.065 & 0.225 & 0.225 & 0.056 & 0.095 & 3.029 \\
\hline 12 & 0.093 & 0.265 & 0.265 & 0.05 & 0.078 & 4.209 \\
\hline 13 & 0.117 & 0.334 & 0.334 & 0.038 & 0.049 & 8.263 \\
\hline 14 & 0.114 & 0.385 & 0.385 & 0.028 & 0.043 & 11.333 \\
\hline 15 & 0.114 & 0.385 & 0.385 & 0.028 & 0.043 & 11.333 \\
\hline 16 & 0.114 & 0.385 & 0.385 & 0.028 & 0.043 & 11.333 \\
\hline 17 & 0.0010 & 0.072 & 0.072 & 0.0090 & 0.322 & 0.352 \\
\hline 18 & 0.117 & 0.334 & 0.334 & 0.038 & 0.049 & 8.263 \\
\hline 19 & 0.114 & 0.385 & 0.385 & 0.028 & 0.043 & 11.333 \\
\hline 20 & 0.065 & 0.225 & 0.225 & 0.056 & 0.095 & 3.029 \\
\hline
\end{tabular}

Langkah selanjutnya dilakukan Metode Algoritma Pembelajaran (Propagasi Error) menggunakan EBP (Error Backpropagation) 


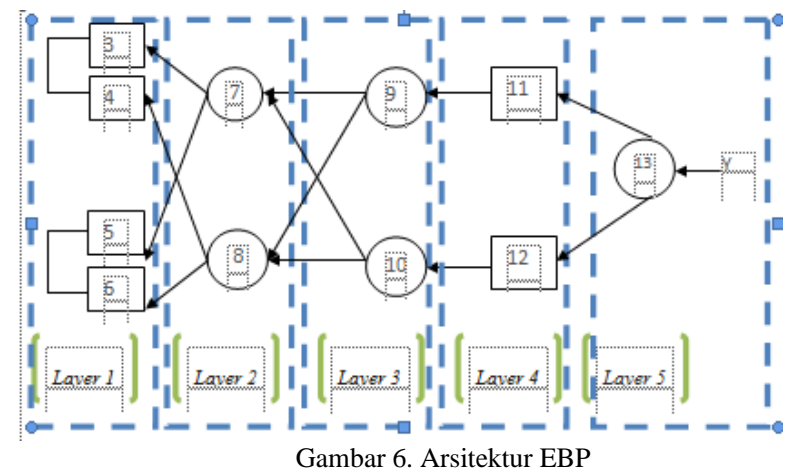

a) Error Pada Lapisan Ke-5

Jaringan adaptif di sini seperti Gambar 5, yang hanya memiliki 1 neuron pada lapisan output (neuron 13)

Tabel 8. Hasil Error Layer 5

\begin{tabular}{|c|c|c|c|}
\hline \multirow{2}{*}{$\begin{array}{l}\text { Data } \\
\text { ke }\end{array}$} & \multicolumn{2}{|c|}{ Input } & Hasil \\
\cline { 2 - 4 } & $\mathrm{yp}_{\mathrm{p}}$ & $\mathrm{y}_{\mathrm{p}}{ }^{*}$ & $\varepsilon_{16}$ \\
\hline 1 & 0.332 & 11.333 & 21.814 \\
\hline 2 & 0.287 & 5.659 & 10.554 \\
\hline 3 & 0.283 & 3.029 & 5.364 \\
\hline 4 & 0.337 & 4.835 & 8.874 \\
\hline 5 & 0.332 & 0.352 & 0.252 \\
\hline 6 & 0.315 & 3.029 & 5.374 \\
\hline 7 & 0.342 & 3.509 & 6.308 \\
\hline 8 & 0.283 & 3.029 & 5.354 \\
\hline 9 & 0.258 & 3.029 & 5.356 \\
\hline 10 & 0.252 & 3.029 & 5.366 \\
\hline 11 & 0.302 & 4.209 & 7.734 \\
\hline 12 & 0.244 & 8.263 & 15.712 \\
\hline 13 & 0.271 & 11.333 & 21.82 \\
\hline 14 & 0.262 & 11.333 & 21.808 \\
\hline 15 & 0.252 & 11.333 & 21.782 \\
\hline 16 & 0.326 & 0.352 & 0.178 \\
\hline 17 & 0.226 & 8.263 & 15.69 \\
\hline 18 & 0.254 & 11.333 & 21.78 \\
\hline 19 & 0.294 & 3.029 & 5.286 \\
\hline 20 & 0.308 & 11.333 & 6.168 \\
\hline
\end{tabular}

b) Error Pada Lapisan ke-4

Lihat kembali gambar Gambar 5 Propagasi error yang menuju pada lapisan ke-4, yaitu neuron 11 dan neuron 12

c) Error Pada Lapisan ke-3

Lihat kembali gambar Gambar 5 Propagasi error yang menuju pada lapisan ke-3, yaitu neuron 9 dan neuron 10

Tabel 9. Hasil Error Layer 4 dan 3

\begin{tabular}{|c|c|c|c|c|c|c|}
\hline \multirow{2}{*}{$\begin{array}{c}\text { Data } \\
\text { ke }\end{array}$} & \multicolumn{3}{|c|}{ Input } & \multicolumn{3}{c|}{ Hasil } \\
\cline { 2 - 7 } & $\varepsilon_{15}$ & $\varepsilon_{14}$ & $\varepsilon_{13}$ & $\varepsilon_{12}$ & $\varepsilon_{11}$ & $\varepsilon_{10}$ \\
\hline 1 & 21.81 & 21.81 & 21.81 & 15.16 & 17.27 & 17.27 \\
\hline 2 & 10.55 & 10.55 & 10.55 & 5.92 & 7.62 & 7.62 \\
\hline 3 & 5.364 & 5.36 & 5.36 & 1.53 & 3.13 & 3.13 \\
\hline 4 & 8.87 & 8.87 & 8.87 & 4.57 & 6.20 & 6.20 \\
\hline 5 & 0.25 & 0.25 & 0.25 & -0.03 & 0.09 & 0.09 \\
\hline 6 & 5.37 & 5.37 & 5.37 & 1.53 & 3.14 & 3.14 \\
\hline 7 & 6.31 & 6.31 & 6.31 & 2.11 & 3.83 & 3.83 \\
\hline 8 & 5.35 & 5.35 & 5.35 & 1.52 & 3.12 & 3.12 \\
\hline 9 & 5.36 & 5.35 & 5.36 & 1.52 & 3.12 & 3.12 \\
\hline 10 & 5.37 & 5.37 & 5.37 & 1.53 & 3.13 & 3.13 \\
\hline 11 & 7.73 & 7.73 & 7.734 & 3.30 & 5.05 & 5.05 \\
\hline 12 & 15.71 & 15.71 & 15.71 & 9.47 & 11.71 & 11.71 \\
\hline 13 & 21.82 & 21.82 & 21.82 & 15.16 & 17.27 & 17.27 \\
\hline 14 & 21.81 & 21.80 & 21.80 & 15.15 & 17.26 & 17.26 \\
\hline
\end{tabular}

\begin{tabular}{|c|c|c|c|c|c|c|}
\hline & & 8 & 8 & 3 & 4 & 4 \\
\hline 15 & 21.78 & 21.78 & 21.78 & 15.13 & 17.24 & 17.24 \\
\hline 16 & 0.18 & 0.19 & 0.18 & -0.02 & 0.067 & 0.067 \\
\hline 17 & 15.69 & 15.69 & 15.69 & 9.46 & 11.69 & 11.69 \\
\hline 18 & 21.78 & 21.78 & 21.78 & 15.13 & 17.24 & 17.24 \\
\hline 19 & 5.29 & 5.29 & 5.29 & 1.504 & 3.084 & 3.084 \\
\hline 20 & 6.17 & 6.17 & 6.17 & 2.323 & 3.884 & 3.884 \\
\hline
\end{tabular}

d)Error Pada Lapisan Ke-2

Lihat kembali gambar Gambar 5 Propagasi error yang menuju pada lapisan ke-2, yaitu neuron 7 dan neuron 8 .

Tabel 10. Hasil Error Layer 2

\begin{tabular}{|c|c|c|c|c|c|c|}
\hline \multirow{2}{*}{$\begin{array}{c}\text { Data } \\
\text { ke }\end{array}$} & $W_{1}$ & $W_{2}$ & $W_{3}$ & $\varepsilon_{9}$ & $\varepsilon_{8}$ & $\varepsilon_{7}$ \\
\hline 1 & 0.028 & 0.04 & 0.007 & 10.0 & 10.0 & 119.869 \\
\hline 2 & 0.058 & 0.05 & 0.011 & 20.0 & 20.0 & 25.282 \\
\hline 3 & 0.056 & 0.09 & 0.019 & 30.0 & 30.0 & 32.058 \\
\hline 4 & 0.065 & 0.06 & 0.012 & 40.0 & 40.0 & 43.853 \\
\hline 5 & 0.009 & 0.32 & 0.081 & 50.0 & 50.0 & 50.045 \\
\hline 6 & 0.056 & 0.09 & 0.019 & 60.0 & 60.0 & 62.062 \\
\hline 7 & 0.041 & 0.09 & 0.024 & 70.0 & 70.0 & 73.632 \\
\hline 8 & 0.056 & 0.09 & 0.019 & 80.0 & 80.0 & 82.054 \\
\hline 9 & 0.056 & 0.09 & 0.019 & 90.0 & 90.0 & 92.054 \\
\hline 10 & 0.056 & 0.09 & 0.019 & 100 & 100 & 102.058 \\
\hline 11 & 0.05 & 0.07 & 0.02 & 110 & 110 & 114.61 \\
\hline 12 & 0.038 & 0.04 & 0.008 & 120 & 120 & 1210.38 \\
\hline 13 & 0.028 & 0.04 & 0.007 & 130 & 1300 & 1319.87 \\
\hline 14 & 0.028 & 0.04 & 0.007 & 140 & 140 & 1419.86 \\
\hline 15 & 0.028 & 0.04 & 0.007 & 150. & 150 & 1519.84 \\
\hline 16 & 0.009 & 0.32 & 0.081 & 160 & 160 & 160.032 \\
\hline 17 & 0.038 & 0.049 & 0.0080 & 170 & 170 & 1710.367 \\
\hline 18 & 0.028 & 0.043 & 0.0070 & 180 & 180 & 1819.838 \\
\hline 19 & 0.056 & 0.095 & 0.019 & 190 & 190 & 192.028 \\
\hline 20 & 0.028 & 0.043 & 0.0070 & 200 & 200 & 202.311 \\
\hline
\end{tabular}

e)Error Pada Lapisan Ke-1

Lihat kembali gambar Gambar 5 Propagasi error yang menuju pada lapisan ke-1, yaitu neuron 6, neuron 5, neuron 4 dan neuron 3 .

Tabel 11. Hasil Error Layer 1

\begin{tabular}{|c|c|c|c|c|c|c|}
\hline \multirow{2}{*}{$\begin{array}{c}\text { Data } \\
\text { ke }\end{array}$} & \multicolumn{7}{|c|}{ Hasil } \\
\hline & $\varepsilon_{1}$ & $\varepsilon_{2}$ & $\varepsilon_{3}$ & $\varepsilon_{4}$ & $\varepsilon_{5}$ & $\varepsilon_{6}$ \\
\hline 1 & 18.72 & 10.0 & 11.53 & 10.0 & 18.722 & 10.0 \\
\hline 2 & 24.31 & 20.0 & 20.375 & 20.0 & 24.31 & 20.0 \\
\hline 3 & 31.63 & 30.0 & 30.146 & 30.0 & 31.636 & 30.0 \\
\hline 4 & 43.51 & 40.0 & 40.274 & 40.0 & 43.514 & 40.0 \\
\hline 5 & 50.00 & 50.0 & 50.003 & 50.0 & 50.008 & 50.0 \\
\hline 6 & 61.63 & 60.0 & 60.146 & 60.0 & 61.639 & 60.0 \\
\hline 7 & 72.88 & 70.0 & 70.236 & 70.0 & 72.887 & 70.0 \\
\hline 8 & 81.63 & 80.0 & 80.146 & 80.0 & 81.633 & 80.0 \\
\hline 9 & 91.63 & 90.0 & 90.146 & 90.0 & 91.633 & 90.0 \\
\hline 10 & 101.6 & 100 & 100.14 & 100 & 101.63 & 100 \\
\hline 11 & 114.4 & 110 & 110.3 & 110 & 114.46 & 110 \\
\hline 12 & 126.3 & 120 & 120.79 & 120. & 126.31 & 120 \\
\hline 13 & 138.7 & 130 & 131.53 & 130 & 138.72 & 130 \\
\hline 14 & 148.7 & 140 & 141.52 & 140 & 148.72 & 140 \\
\hline 15 & 158.7 & 150 & 151.52 & 150 & 158.71 & 150 \\
\hline 16 & 160.0 & 160 & 160.00 & 160 & 160.00 & 160 \\
\hline 17 & 176.3 & 170 & 170.79 & 170 & 176.30 & 170 \\
\hline 18 & 188.7 & 180 & 181.52 & 180 & 188.70 & 1800 \\
\hline 19 & 191.6 & 190 & 190.14 & 190 & 191.61 & 190 \\
\hline 20 & 202.2 & 200.0 & 200.164 & 200.0 & 202.239 & 200.0 \\
\hline & & & & & \\
& & & & & & \\
& & & & & & \\
\hline
\end{tabular}


Selanjutnya nilai error tersebut kita gunakan untuk mengupdate parameter $\mathrm{a}_{\mathrm{i}}, \mathrm{b}_{\mathrm{i}}$ dan $\mathrm{c}_{\mathrm{i}}$ baru.

Tabel 12. Hasil Update $a_{i}$ and $b_{i}$ baru

$\Delta \mathrm{a}_{\mathrm{ij}}=\mu \varepsilon \mathrm{a}_{\mathrm{ij}} \mathrm{x}_{\mathrm{i}} \mathrm{dan} \ldots .$.

$\Delta \mathrm{c}_{\mathrm{ij}}=\mu \varepsilon \mathrm{c}_{\mathrm{ij}} \mathrm{X}_{\mathrm{i} \ldots}$

Sehingga nilai aij dan cij yang baru pada data ke-p adalah :

$\mathrm{A}_{\mathrm{ij}}=\mathrm{a}_{\mathrm{ij}}(\mathrm{lama})+\Delta \mathrm{a}_{\mathrm{ij}} \mathrm{dan}$

$c_{i j}=c_{i j}($ lama $)+\Delta c_{i j}$

Setelah didapatkan nilai baru maka proses selanjutnya adalah mengupdate nilai jaringan ANFIS yang baru agar didapat hasil output yang baru.

Selisih antara ANFIS sebelum di update dan ANFIS setelah di update dengan nilai $a_{\mathrm{ij}}$ dan $\mathrm{c}_{\mathrm{ij}}$ yang baru ini menjadi error. Dan nilai error ini diambil dari nilai terkecil untuk mengetahui data keberapa yang akan disimulasikan.

Tabel 13. Hasil Output awal dan Output Update

\begin{tabular}{|c|c|c|c|}
\hline \multirow{2}{*}{$\begin{array}{l}\text { Data } \\
\text { ke }\end{array}$} & Output Awal & $\begin{array}{c}\text { Output } \\
\text { Update }\end{array}$ & |error| \\
\cline { 2 - 3 } & $\sum \bar{w}_{i} f_{i}$ & $\sum \bar{w}_{i} f_{i}$ & \\
\hline 1 & 33.597 & 40.027 & 6.43 \\
\hline 2 & 17.394 & 30.111 & 12.717 \\
\hline 3 & 11.065 & 16.512 & 5.447 \\
\hline 4 & 15.186 & 26.68 & 11.494 \\
\hline 5 & 3.105 & 0.582 & 2.523 \\
\hline 6 & 11.065 & 16.512 & 5.447 \\
\hline 7 & 12.54 & 18.081 & 5.541 \\
\hline 8 & 11.065 & 16.512 & 5.447 \\
\hline 9 & 11.065 & 16.512 & 5.447 \\
\hline 10 & 11.065 & 16.512 & 5.447 \\
\hline 11 & 14.053 & 19.991 & 5.938 \\
\hline 12 & 25.234 & 33.952 & 8.718 \\
\hline 13 & 33.597 & 40.027 & 6.43 \\
\hline 14 & 33.597 & 40.027 & 6.43 \\
\hline 15 & 33.597 & 40.027 & 6.43 \\
\hline 16 & 3.105 & 0.583 & 2.522 \\
\hline 17 & 25.234 & 33.952 & 8.718 \\
\hline 18 & 33.597 & 40.027 & 6.43 \\
\hline 19 & 11.065 & 16.512 & 5.447 \\
\hline 20 & 11.872 & 15.955 & 4.083 \\
\hline & & & \\
\hline
\end{tabular}

\subsection{Desain Program}

Secara garis besar desain sistem program ini terdiri dari beberapa bagian diantaranya input, proses pengolahan dan output ini untuk program simulasi dan untuk program grafik juga hampir sama diantaranya input, proses pengolahan dan output. Input dari sistem berupa data hasil

observasi berupa data morfologi tanaman. Data tersebut diantaranya tinggi tanaman, panjang batang, banyak cabang dan banyak daun.

Selanjutnya data morfologi tersebut diolah dalam proses pengolahan input menggunakan ANFIS (Adaptive Neuro Fuzzy Inference System). Sedangkan output berupa model simulasi morfologi tanaman yang datanya diperoleh dari hasil output proses. Desain ANFIS dan Desain ANFIS dengan GroIMP pada gambar 7 dan gambar 8 .

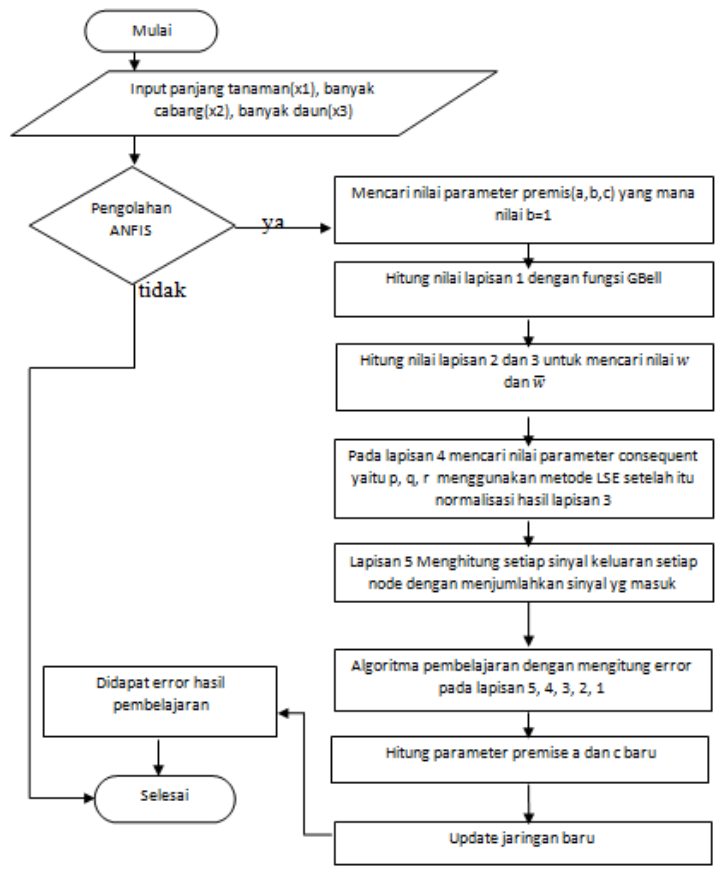

Gambar 7. Flowchart ANFIS

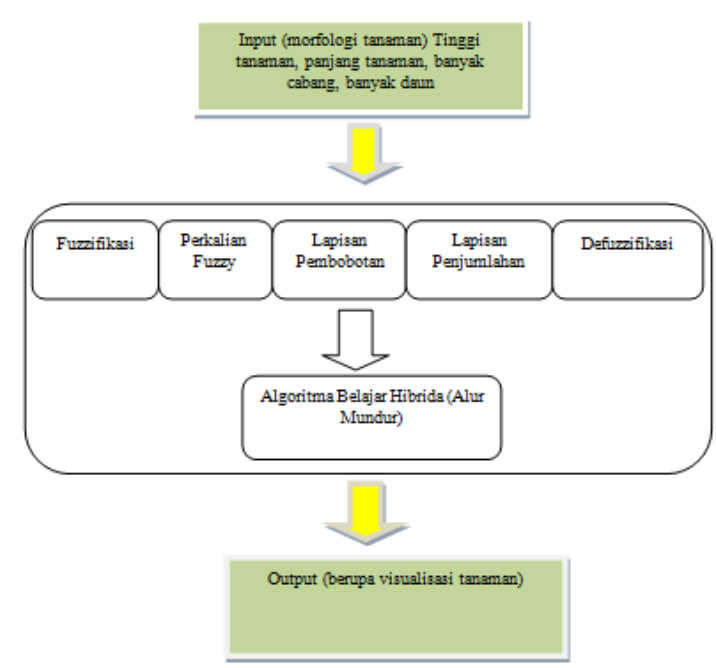

Gambar 8. Desain ANFIS dengan GroIMP

\subsection{Pembuatan Program}

Pembuatan program simulasi ini dilakukan sebanyak dua kali. Bagian pertama yaitu proses pembuatan program perhitungan ANFIS berdasarkan data-data yang diperoleh dari penelitian. Bagian kedua yaitu proses pembuatan visualisasi output ANFIS yang berupa simulasi pertumbuhan tanaman kedelai. 


\subsection{Hasil Program}

Hasil program simulasi ini berupa tampilan simulasi 3D yang disertai dengan keterangan tinggi tanaman,

jumlah cabang, jumlah daun, waktu, dan hari dan grafik pada setiap jalanya pertumbuhan. Berikut adalah gambar hasil program simulasi :
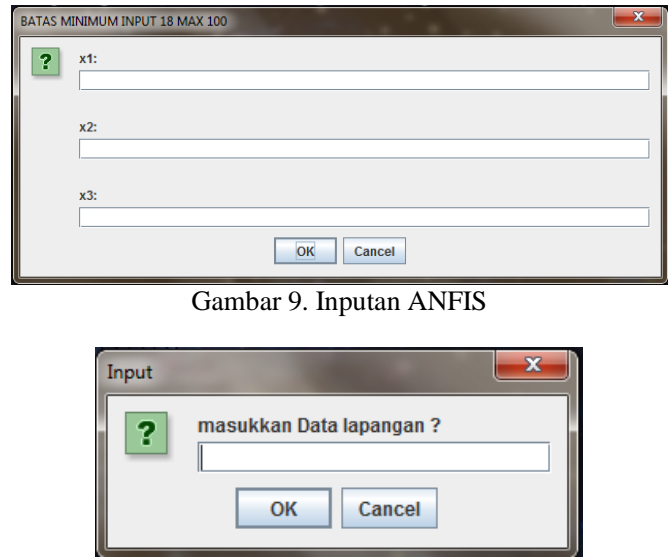

Gambar 10. Inputan Grafik

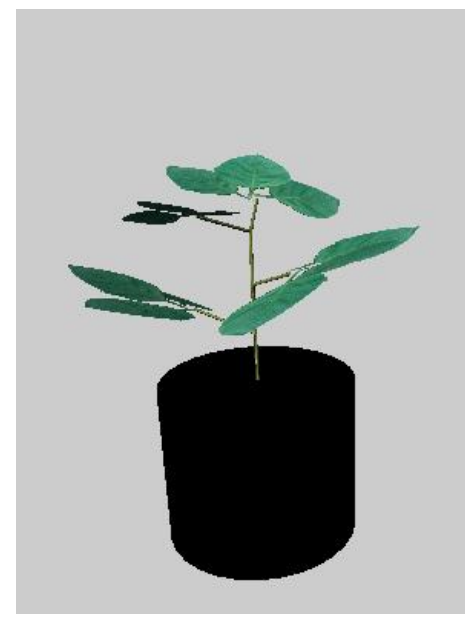

Gambar 11. Simulasi Kedelai GroIMP

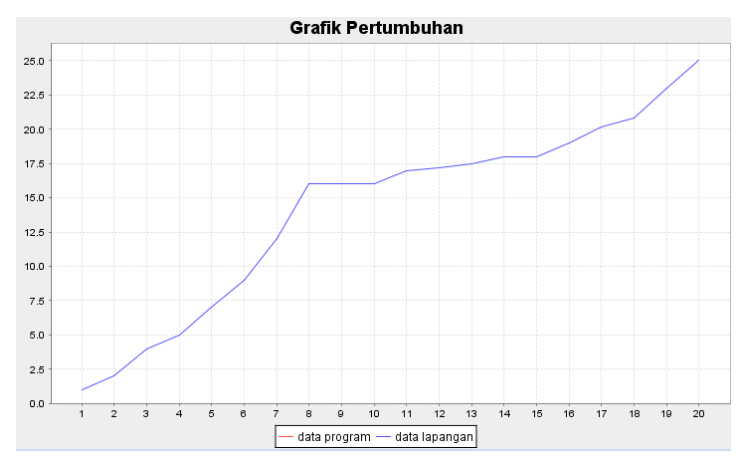

Gambar 12. Hasil Inputan data lapangan

\section{KESIMPULAN}

Dari hasil observasi tanaman kedelai didapat tanaman dengan ciri-ciri etiolasi pada umur 10 hari hingga 28 hari dan dilakukan pemindahan tempat yang lebih lapang namun hasilnya tanaman masih tetap menunjukan gejala etiolasi karena daun dan cabang banyak namun dan rimbun tapi batang kecil dan pada umur tanaman harus sudah berbunga tapi masih belum berbunga. setelah dilakukan percobaan dengan Lux Meter didapat intensitas cahaya matahari rata-rata pada bulan Januari sebesar 230.61 $\mathrm{cal} / \mathrm{cm} 2 /$ hari dan terendah $217.82 \mathrm{cal} / \mathrm{cm} 2 / \mathrm{hari}$. Keadaan iklim tersebut menunjukan kondisi cuaca memungkinkan tanaman terkena etiolasi dan lingkungan yang tidak mendukung. Setelah itu didapat hasil pada Pemberian pupuk Anorganik jenis Urea 2 gr/liter dapat meningkatkan tinggi tanaman lebih cepat daripada menggunakan pupuk Organik Cair 3 cc/liter, banyak cabang dan banyak daun juga lebih terlihat pengaruhnya ketika menggunakan pupuk Urea daripada pupuk organik. Lama penyinaran juga mempengaruhi baik tidaknya tanaman kedelai. Pada pembuatan program simulasi pertumbuhan kedelai ini, dapat disimpulkan bahwa secara umum program simulasi dengan menggunakan metode ANFIS (Adaptive Neuro Fuzzy Inference System) dapat menggambarkan pola pertumbuhan dan perkembangan tanaman Kedelai varietas Wilis dengan rata-rata presentase akurasi tinggi tanaman dan jumlah daun dan jumlah cabang pada percobaan pertama sebesar 7,3284\% dan pada percobaan ke 2 sebesar 7,329354651\%.

\section{REFERENCES}

[1]. Adisarwanto, T. (2005). 'Meningkatkan Produksi Kacang Tanah di Lahan Sawah dan Lahan Kering'. Panebar Swadaya. Jakarta. Hal 23

[2]. Nezhad, Q.A., Zand, J.P. \& Hosaini, S.S. (2013). 'An investigation on fuzzy logiccontrollers (takagi-sugeno \& mamdani) in inverse pendulum system'.International Journal of Fuzzy Logic Systems3(3): hal. 1-13

[3]. Jang, Jyh-Shing Roger; (1993). 'ANFIS: Adaptive-network based fuzzy inferencesystem; Departement of Electrical Engineering and Computer Science',University of California.

[4]. Fariza, A. (2007). 'Performansi Neuro Fuzzy untuk Peramalan Data Time Series', Seminar Nasional Aplikasi Teknologi Informasi. SNATI. Yogyakarta.

[5]. Nuryani, S dan Handayani. (2003). 'Sifat Kimia Entisol pada Sistem Pertanian Organik'. Jurnal Ilmu Pertanian Vol.10 No.2: Hal. 63-69.

[6]. Soegiman. (1982). 'Ilmu Tanah. Terjemahan dari Buckman, H. O dan Brady, N. C.The Nature and Properties of soil'. Bharata Karya Aksara. Jakarta. Hal 75

[7]. Sutanto, R., (2002). 'Penerapan Pertanian Organik. Permasyarakatan danPengembangannya. Penerbit Kanisius. Yogyakarta. Hal 113

[8]. Kusumadewi, Sri dan Purnomo Hari. (2010), 'Aplikasi Logika Fuzzy',Cetakan Pertama, Graham Ilmu, Yogyakarta. Hal 47

[9]. Sugiyono. (2013). 'Metode Penelitian Pendidikan Pendekatan Kuantitatif, Kualitatif, dan R\&D'. Bandung: Alfabeta.

[10]. Albab, Muhammad Ulil. (2013). 'Rancang Bangun Sistem Kamera Pemantau Bergerak Dengan Keypad Sebagai Pengendali Manual Motor Servo. Politeknik Negeri Sriwijaya.

[11].Kusumadewi, Sri.,Hartati, S., Harjoko, A., dan Wardoyo, R. (2006). Fuzzy Multi - Attribute 
Decision Making (FUZZY MADM). Graha Ilmu, Yogyakarta, Hal 63

[12]. Iswanto, Candra, Hadi. (2011). 'Penerapan Stochastic L-System Pada Pemodelan Pertumbuhan Batang Tanaman', In Reporsitory UNEJ. Available at :https://repository.unej.ac.id/handle/123456789 $/ 13416$

[13]. Siderska, Julia. (2016). 'Application Of Tecnomatix Plant Simulation Formodeling Production And Logistics Processes' in Journal Business, Management and education Vol. 14 no. 1. Available at : https://journals.vgtu.lt/index.php/BME/article/ download/2150/1735

[14]. Pembengo, Wawan., Suwarto. (2012). 'Model Simulasi Pertumbuhan Dan Produksi Tanaman Tebu', in Jurnal Agroteknotropika, Vol 1, No 1. Available at: http://ejurnal.ung.ac.id/index.php/JATT/article/ view/490

[15]. Dominiri, Dede, Dirgahayu. (2011). 'Aplikasi Simulasi Model Dinamis Pertumbuhan Tanaman Untuk Menduga Produksi Tanaman Padi', in Journal penginderaan jauh dan pengolahan citra digital, vol 8, 35-49. Available at :

http://jurnal.lapan.go.id/index.php/jurnal_inder aja/article/view/1611

[16]. Gromikora, Nope and Yahya, Sudirman and Suwarto. (2014). 'Permodelan Pertumbuhan dan Produksi Kelapa Sawit pada Berbagai Taraf Penunasan Pelepah' in Jurnal Argonomi Indonesia, Vol. 42 no. 3, availabe at: http://journal.ipb.ac.id/index.php/jurnalagrono mi/article/view/9179 